\title{
THE FUNCTIONING OF URBAN HOTELS IN THE NATURAL ENVIRONMENT
}

Daniel Puciato, Ph.D., Associate Professor

Opole University of Technology

Faculty of Physical Education and Physiotherapy

Department of Tourism and Recreation

Prószkowska 76, 45-758 Opole, Poland

e-mail:d.puciato@po.edu.pl

ORCID: 0000-0002-2390-6038

Received 16 April 2020, Accepted 26 September 2020

\begin{abstract}
Research background: There are numerous interactions between the natural environment and a hotel company. On the one hand, the natural environment affects the hotel; on the other hand, the hotel has a significant impact on the environment. Dynamic changes in the natural environment and their effects on the functioning of hotels make it important to assess the strength and directions and to identify the conditions and consequences of these mutual interactions.

Purpose: The paper aims to assess interactions taking place between the natural environment and hotels located in Wroclaw, Poland.

Research methodology: The main research method was a diagnostic questionnaire survey. The study was carried out 2017 among the owners or managers of 24 hotels from Wrocław. Chi-squared tests were conducted and Cramer's V measures of association were calculated. The level of statistical significance was set at ex ante $\alpha=0.05$.

Results: In the opinion of the highest percentage of respondents, interactions between the natural environment and Wroclaw hotels are of low strength and are neutral. The hotel type was associated with the strength of the environmental impact on the hotel. In the Wrocław hotels that were researched there were significant correlations between the strength of the hotel's impact on the natural environment, hotel specific location, and quality standard (hotel rating).

Novelty: Potential correlations between the strength and directions of interactions between hotels, as well as between the natural environment and organizational and functional characteristics of urban hotels have not been researched before.
\end{abstract}

Keywords: urban hotels, natural environment, Wrocław hotel industry

JEL classification: L83, Q56, Z32 


\section{Introduction}

Economic growth has a number of benefits and disadvantages. The most significant of the latter are negative changes in environmental quality and the depletion of natural resources. The natural environment is an essential part of every business's surroundings, which is particularly evident in the case of tourism operators. In this context, hotels should be regarded as particularly interesting types of tourism market entities. There are several reasons for this. Firstly, the hotel industry is the main part of tourism economy in terms of the generated income and employment. Secondly, the dynamic development of the hotel market, which is currently also observed in Poland, is not indifferent to the natural environment. Thirdly, the specificity of tourist trips may sometimes favor negative environmental behaviors of hotel guests. Fourthly, hotel market entities are characterized by their organizational diversity, which may be not insignificant in their approach to the natural environment.

There are mutual interactions between the natural environment and the hotel business. On the one hand, the natural environment influences the running of hotels; on the other hand, hotels exert a considerable impact on the natural environment. The condition of environmental components, the size of available natural resources, and the possibility of finding attractive locations for new hotel facilities, necessitate certain actions, both at the stage of site selection, design, and construction; as well as during the operation of hotels. Paradoxically, however, mainly in the short term, even negative changes in the natural environment can be seen as potential opportunities, mainly for facilities located in particularly attractive tourist destinations with a low degree of environmental degradation. This also applies to capital-strong hotel chains, which, with adequate resources (human, informational, financial) can acquire such locations for their new facilities (Puciato, 2016; Puciato, Dziedzic, 2017).

It is worth noting that the influence of the natural environment on the functioning of hotels is not only direct, but also involves indirect effects on the hotel's micro- and macro-surroundings (Adamczyk, Nitkiewicz, 2007; Chen, 2019; Han, Yu, Hyun, 2020; Li, Lu, Xu, Sun, 2020; Yu, Ariza-Montes, Hernandez-Perlines, Vega-Munoz, Han, 2020). The former include suppliers (availability and costs of obtaining raw materials, environmental requirements), customers (ecological marketing, pro-environmental orientation), employees (health and quality of life), owners (impact on company value, ecological risk), and local community (state of the environment and quality of life in tourist reception areas). The effects of macro-surroundings can be global (bad state of the environment as a global problem), economic (ecological investments, "green" fiscal policies), political (obligations and ratified agreements, distribution of forces on the 
political scene), legal (environmental law, including legislative acts, environmental standards), and technological (emphasis on generating effective pro-ecological and cost-effective technical solutions).

A hotel's impact on the natural environment is complex. Business activities in the hotel sector are associated with negative consequences for the natural environment, resulting from, e.g., emission of gas and dust air pollutants, discharges of pollutants into waters and soils, water intake, or noise generation (Asadi et al., 2020; Kiryluk, Borkowska-Niszczota, 2006). However, some hotel businesses may also produce environmental benefits, mainly in terms of raising environmental awareness among hotel stakeholders, e.g. employees and guests. Positive proenvironmental behaviors resulting from increased awareness may then be projected to the hotel surroundings, and implemented in completely different locations (Chan, 2009; Chan, Wong, 2006; Puciato, Goranczewski, 2011).

The high significance and deteriorating quality of the natural environment makes it increasingly necessary for international institutions, central authorities, as well as local communities, authorities and organizations to undertake joint measures aimed at building a sustainable society (Saito, 2017). Alternative development theorems are also constantly being sought, the most important of which is undoubtedly the paradigm of development which is sustainable, durable, and self-sustaining (Borys, 2011). This theorem is also the basis of the concept of sustainable (green, eco-friendly) tourism, whose objective is to organize and operate an economy enabling the long-term uses of tourism assets. The pro-ecological development of tourism, including the hotel industry, is related to both its supply side - the "greening" of regions, products and hotel staff - and to its demand side - the "greening" of consumption (Kiryluk, Borkowska-Niszczota, 2006). Niezgoda (2004) and Strzembicki (2001) also identified six principles of sustainable tourism: (1) promotion of a healthy lifestyle among hotel guests, employees, managers, and its harmonious coexistence with the natural environment; (2) preservation of biodiversity and protection of the cultures of indigenous communities; (3) participation of inhabitants of reception areas in tourism policy; (4) elimination of substances harmful to the environment, as well as the reduced use of resources for providing services and curbing the negative effects of these activities; (5) endeavoring to increase the environmental awareness of hotel stakeholders; and (6) strict compliance with legal and ethical regulations concerning the environmental standards of tourism, including the hospitality industry.

The concept of sustainable development is also reflected in the hotel companies themselves, which usually carry out a number of pro-ecological activities. The direct reasons for their implementation can be arranged in four groups (Kożuch, 2012): (1) legal requirements 
- instruments of direct impact; (2) technological progress generating high-efficiency solutions; (3) marketing activities related to the strategy of developing a "pro-ecological" image of the hotel; and (4) economic instruments resulting from the microeconomic profitability of green investments.

The profitability of the pro-ecological activities of hotels, which involves comparing the costs of the emission of pollutants with the costs of their reduction, should be seen as key in the context of the present study. The costs of pollution emissions are different types of ecological charges for economic use of the environment, quantitative degradation of the environment, pollution of various environmental components (qualitative degradation of the environment), utility and products, the necessity to acquire transferable pollution emission rights, ecological insurances, and the potential expenses of removing the effects of ecological disasters (Fiedor, 2002). The reduction costs can be divided into current and investment ones. The former are related to protective equipment, research and development, educational activities, and environmental management (general costs) as well as environmental monitoring (costs of other activities). Investment expenditure includes methods, technologies, processes and equipment, whose main purpose is to collect, monitor, reduce, prevent or eliminate pollution or environmental losses (Fura, 2011). The most obvious situation in which the pro-environmental measures will absolutely be implemented by the hotel is the one in which the costs of emissions exceed the costs of reduction. However, if a hotel company is induced to undertake such actions due to legal, marketing, or technical reasons, they will also be implemented in situations where both groups of costs are balanced, and even where the costs of reduction are higher than the costs of emissions.

With respect to specific environmental actions (practices) implemented in a hotel, it should be noted that the most elementary (primary) manifestation of the concept of sustainable development is the pro-environmental behaviors of various hotel stakeholder groups, i.e. customers, employees, managers, owners and suppliers (Bugdol, Puciato, Boris, 2019). Proenvironmental behaviors are based on such environmental management practices as corporate social responsibility, standardized management systems, or functional-environmental strategies (Fraj, Matute, Melero, 2015; Jedynak, 2017; Najda-Janoszka, 2010; Puciato, Goranczewski, 2011; Raczkowski, Sułkowski, Fijałkowska, 2016).

The interactions between the natural environment and the hotel are not only of great practical importance but also of cognitive significance, thus being a considerable number of research studies in Poland and abroad. The first group of these studies deals with the issue of the functioning of hotels in their macro-surroundings, including the natural 
environment. Sidorkiewicz and Tokarz (2011), for example, analyzed the role of environmental risk in the hotel management process. Puciato and Żmigrodzki (2009) focused on identifying the directions of the impact of macro-surroundings on hotels, including the significance of natural assets for hotels' business success. The second research area focuses on the proenvironmental behaviors of hotel stakeholders. Juvan and Dolnicar (2017) identified several main drivers of pro-environmental behaviors of hotel guests, implemented at the first stage of tourist consumption, i.e. preparation for departure. A certain percentage of potential tourists were found to even declare to give up traveling in order to reduce the pressure on the natural environment. The implemented behaviors also included choosing a tourist destination near one's place of residence, using low-emission tourist transport, rejecting tourist offers that do not include pro-environmental activities, or using only the offers of tourist companies with environmental certificates. However, the results of research conducted in Polish hotels were less optimistic. Kapera and Wszendobyl-Skulska (2017) observed that only one-third of respondents took environmental considerations into account when selecting a hotel. However, Ozimek, Szlachciuk, Kulykovets and Przeździecka-Czyżewska (2017) showed that potential guests do not consider environmental issues at all in the process of selecting a hotel. The reasons for this were sought by Bugdol, Puciato and Borys (2019), who identified the main barriers to the development of pro-environmental behaviors in hotels resulting from cognitive limitations, specificity of the hotel industry, insufficient implementation or quality of implemented environmental practices, low credibility of operators, unclear motives for action, and lack of conviction that positive changes in environmental awareness automatically translate into actual purchases of "sustainable hotel products". The third research area concerns the issue of environmental management in hotels. Kłos (2013) provided examples of the most popular environmental management practices in hotels, i.e. environmental management systems and ecolabels, working with the local population, or stimulation of environmental awareness. Also Niezgoda and Markiewicz (2015), Borkowska-Niszczota (2015), and Kapera (2018) provided examples of environmental management measures, but placed them in the context of tourism sustainability. Their research results show that hotels strive to prevent pollution, ensure the sustainable use of raw materials, and mitigate climate change. Hotels also apply a wide range of pro-environmental solutions for waste and wastewater management, saving electricity and heating energy, and reducing water consumption. Hotel guests are also involved in some of these activities and hotel companies are open to guests' suggestions for environmental solutions that could be applied in the facilities. Sztorc (2017), on the other hand, addressed the question of incorporating organizational (ecological) values into hotel development strategies. Ouyang, 
Wei and Chi (2019) demonstrated the role of the institutional environment in implementing environmental management systems in hotels. Panasiuk (2017) focused on the subject of EU funds as a potential source of financing ecological investments in hotels. The fourth area of research tackled the environmental efficiency of hotels. Yucedag, Kaya and Cetin (2018) noted in their study that pro-environmental behaviors and actions can contribute to lower ecological and financial costs of hotels. Yusoff, Nejati and Kee (2018) and Kim, Kim, Choi and Phetvaroon (2019) demonstrated that the environmental behaviors and practices have a positive impact on the environmental performance of hotels.

The analysis of literature on the relationships between hotels and the natural environment indicates the existence of several key research gaps:

1. The majority of the studies to date treat the natural environment as one of many areas of hotel macro-surroundings, which determines a fairly synthetic approach to the issue.

2. The assessment of the strength and directions of the impact of the natural environment on hotels, and hotels on the natural environment, in the opinion of owners or managers has not been thoroughly studied.

3. So far the research has included almost exclusively hotels located in tourist resorts, while city hotels have been treated marginally, considering only the business segment.

4. There have been no studies examining correlations between the strength and direction of environment-hotel interactions and the organizational and functional characteristics of hotel enterprises.

Within the context of the foregoing introductory remarks, the aim of this article is to assess the interactions between the natural environment and hotels located in Wrocław (Poland). This aim is specified in more detail regarding the following research problems:

1. What are the strength and directions of the environmental impact on the hotels under study?

2. What are the strength and directions of influence of the surveyed hotels on the natural environment?

3. What are the effects of the environmental impact on the surveyed hotels?

4. What are the results of the impact of the surveyed hotels on the natural environment?

5. Are the strength and directions of the environmental impact on the studied hotels related to their organizational and functional characteristics?

6. Are the strength and directions of the impact of the hotels on the natural environment linked to the organizational and functional characteristics of the surveyed enterprises? 


\section{Methods}

Three main research methods used in the paper were: deduction, documentation method, and diagnostic questionnaire survey. The deduction method was used to analyze the literature and source materials. The data from Statistics Poland and the Central Register of Hotel Facilities of the Polish Ministry of Sport and Tourism were used to take an inventory of hotels located in the Wrocław area. Then, based on the diagnostic survey method, a questionnaire was used related to selected aspects of hotel operations in the surroundings, consisting of 16 open, semiopen and closed questions, and a respondent's particulars section. Before the commencement of the study the questionnaire was subjected to pilot tests, and all detected errors were corrected. The survey was conducted from April to June 2017 among the owners or managers of 24 hotels in Wrocław, who agreed to participate in the poll. This accounted for approximately $51 \%$ of such facilities located in Wrocław.

Table 1. Characteristics of the surveyed hotels $(n=24)$

\begin{tabular}{|c|c|c|}
\hline Criterion & Number of hotels & Percentage of hotels \\
\hline \multicolumn{3}{|c|}{ Integration } \\
\hline Independent & 13 & 54.17 \\
\hline Integrated (chain hotels) & 11 & 45.83 \\
\hline \multicolumn{3}{|l|}{ Hotel type } \\
\hline Tourist & 10 & 41.67 \\
\hline Business & 14 & 58.33 \\
\hline \multicolumn{3}{|l|}{ Hotel size } \\
\hline Small & 11 & 45.83 \\
\hline Medium & 12 & 50.00 \\
\hline Large & 1 & 4.17 \\
\hline \multicolumn{3}{|c|}{ Hotel rating } \\
\hline$*$ & 2 & 8.33 \\
\hline$* *$ & 2 & 8.33 \\
\hline$* * *$ & 12 & 50.00 \\
\hline$* * * *$ & 5 & 20.83 \\
\hline$* * * * *$ & 3 & 12.50 \\
\hline \multicolumn{3}{|c|}{ Location } \\
\hline Outskirts & 12 & 50.00 \\
\hline City center & 12 & 50.00 \\
\hline
\end{tabular}

Source: author's own on the basis of survey results. 
Taking into account the degree of integration with other business entities, thirteen $(54.2 \%)$ independent hotels and eleven (45.8\%) chain hotels can be distinguished among the surveyed facilities. Considering the size criterion defined by Bednarska et al. (2007), one half of the surveyed hotels (50\%) were of medium size (50 to 200 rooms), eleven (45.8\%) - small (below 50 rooms), and one (4.2\%) - large (more than 200 rooms). Following the hotel rating criterion, half of them $(50 \%)$ were three-star, five $(20.8 \%)$ - four-star, three $(12.5 \%)$ - five-star, two twostar $(8.3 \%)$, and two one-star $(8.3 \%)$ hotels. Given the specific location of hotels in the sample, twelve $(50 \%)$ hotels were located in the city center and twelve on the outskirts of Wrocław (Table 1).

Based on the research results, the number and percentage of answers to individual questionnaire items was determined. Chi-squared distribution $\left(\chi^{2}\right)$ and Cramer's V measures of association were calculated. Statistical conclusions were made at the ex ante level of significance of $\alpha=0.05$. The results are presented in the figures and tables below.

\section{Results}

Figures 1 and 2 show the results of the assessment of the strength and directions of interactions between the natural environment and the studied hotels. The low strength of the influence of the natural environment on the hotel was observed by $37.5 \%$, high by $33.3 \%$, and average by $29.2 \%$ of the surveyed hotel managers or owners. The highest percentage of respondents $(45.8 \%)$ representing the Wroclaw hotel market concluded that the natural environment was neutral towards the hotel. The positive role of the natural environment for the functioning of their hotels was noticed by $37.5 \%$, while the negative role by $16.6 \%$ of the respondents. Half of the respondents (50\%) assessed the strength of the hotel's impact on the natural environment as low, while $25 \%$ of the respondents assessed it as high and average. Neutral influence was indicated by $37.5 \%$, positive by $33.3 \%$, and negative by $29.2 \%$ of respondents.

Tables 2 and 3 show the most significant effects (positive and negative) of the interaction of the natural environment with the surveyed Wrocław hotels. The respondents could give more than one answer in this part of the questionnaire; therefore their respective percentages do not add up to 100. The representatives of the Wrocław hotels considered the following as the most important positive effects of the environmental impact on their businesses: possibility to use natural resources, mainly water, air, energy, and location (75\%); availability of resources necessary for their providing of services, e.g. food, paper, or wood $(58.3 \%)$; and the possibility to operate in an attractive geographical location (25\%). The main negative environmental effects 
of the location of hotels in Wrocław included polluted air (75\%) and shortage and low quality of natural assets, i.e. flora and fauna (25\%).

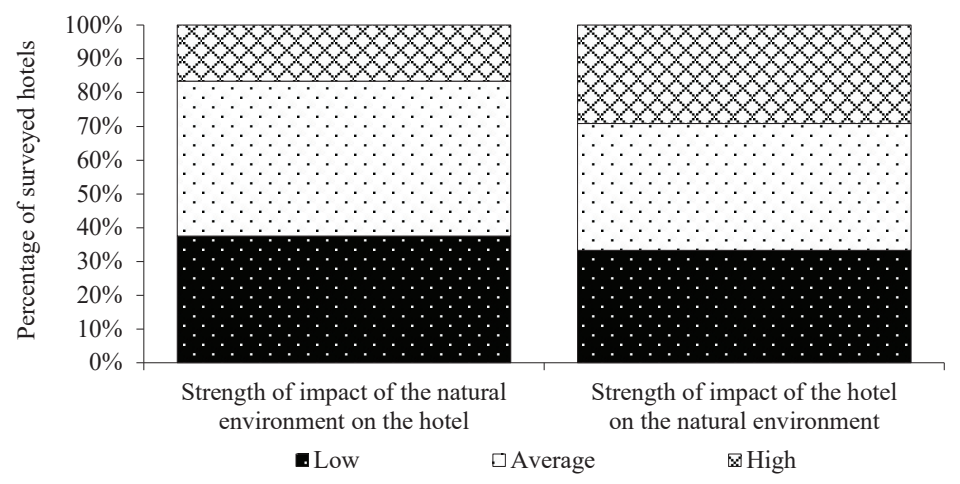

Figure 1. Strength of mutual influence between the hotel and the natural environment in respondents' opinions

Source: author's own on the basis of the results of the survey.

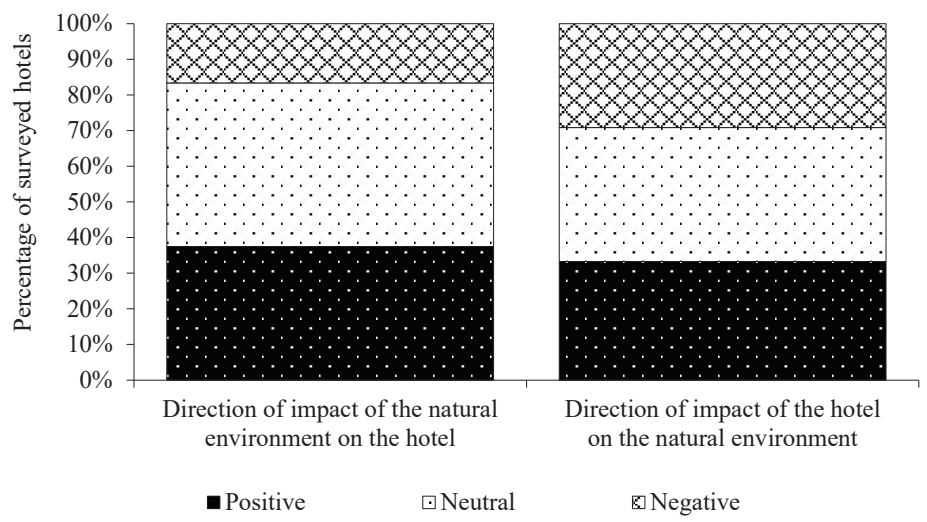

Figure 2. Direction of mutual influence between the hotel and the natural environment in respondents' opinions

Source: author's own on the basis of the results of the.

The respondents also identified the positive effects of the functioning of their hotels in a specific natural environment. Almost three-fourths (70.8\%) stated that their business contributed to the improvement of the environmental awareness of hotel stakeholders, mainly employees, guests, and suppliers. Prevention of air, water and soil pollution was indicated by 
$20.8 \%$; limited volume of resources by $16.7 \%$, while the use of recycled materials by $8.3 \%$ of respondents. The identified benefits resulted, in respondents' opinion, from a number of measures undertaken by the hotels, i.e.: the use of a pro-ecological infrastructure, use of lowemission energy resources, implementation of environmental management practices (strategies, policies, systems, methods and tools), or investments in business development, including the training of employees. The respondents also noticed some negative effects of the operation of their hotels on the natural environment, which included water consumption (79.2\%), waste generation $(45.8 \%)$, pollution emissions $(29.2 \%)$, sewage production $(25 \%)$, and food waste $(20.9 \%)$.

Table 2. Effects of impact of the natural environment on hotels $(n=24)$

\begin{tabular}{|c|c|c|}
\hline Effect & Number of hotels & Percentage of hotels \\
\hline \multicolumn{3}{|c|}{ Positive } \\
\hline Use of natural resources & 18 & 75.00 \\
\hline Availability of resources necessary for providing services & 14 & 58.33 \\
\hline Attractive geographical location & 6 & 25.00 \\
\hline \multicolumn{3}{|c|}{ Negative } \\
\hline Air pollution & 18 & 75.00 \\
\hline Shortage of natural assets & 6 & 25.00 \\
\hline
\end{tabular}

Source: author's own on the basis of the results of the survey.

Table 3. Effects of the impact of hotels on the natural environment $(n=24)$

\begin{tabular}{|c|c|c|}
\hline Effect & Number of hotels & Percentage of hotels \\
\hline \multicolumn{3}{|c|}{ Positive } \\
\hline Environmental awareness improvement & 17 & 70.83 \\
\hline Pollution prevention & 5 & 20.83 \\
\hline Limited volume of used resources & 4 & 16.67 \\
\hline Use of recycled materials & 2 & 8.33 \\
\hline \multicolumn{3}{|c|}{ Negative } \\
\hline Water consumption & 19 & 79.17 \\
\hline Waste generation & 11 & 45.83 \\
\hline Pollution emissions & 7 & 29.17 \\
\hline Sewage production & 6 & 25.00 \\
\hline Food waste & 5 & 20.83 \\
\hline
\end{tabular}

Source: author's own on the basis of the results of the survey. 
The results of the analysis of the potential correlations between the strength and directions of interactions between the natural environment and the hotel and organizational and functional characteristics of hotel facilities are presented in Tables 4-7. The average and high strength of the environmental impact on the hotel business was indicated by the vast majority (92.9\%) of hotel representatives, while low strength by as many as $70 \%$ of owners or managers of tourist hotels. The value of $\chi^{2}=10.47$ was statistically significant at $p=0.01$. Therefore, at the level of significance of $1 \%$ it can be stated that the type of a hotel was correlated with the strength of the impact of the natural environment on it. The value of Cramer's V of 0.66 indicates a high correlation between the strength of the environmental impact on the hotel and the type of hotel. No analogous correlations were found with respect to the strength of the environmental impact on the hotel and its size, specific location, hotel rating and degree of integration. In the last variable, however, the results were close to statistical significance $(p=0.06)$. In the surveyed enterprises, however, the assessment of the directions of the environmental impact on a hotel was not statistically significant for any of the organizational and functional characteristics of the surveyed hotels (Tables 4, 5).

Table 4. The strength of the impact of the natural environment on hotels and selected functional characteristics of hotels

\begin{tabular}{|c|c|c|c|c|c|c|c|c|c|c|}
\hline \multirow{3}{*}{$\begin{array}{l}\text { Functional } \\
\text { characteristic }\end{array}$} & \multirow{3}{*}{ Variable } & \multicolumn{6}{|c|}{$\begin{array}{l}\text { Strength of impact of the natural environment } \\
\text { on hotels }\end{array}$} & \multirow{3}{*}{$\chi^{2}$} & \multirow{3}{*}{$\mathrm{p}$} & \multirow{3}{*}{$\mathrm{V}_{\mathrm{c}}$} \\
\hline & & \multicolumn{2}{|c|}{ large } & \multicolumn{2}{|c|}{ medium } & \multicolumn{2}{|c|}{ small } & & & \\
\hline & & $\mathrm{n}$ & $\%$ & $\mathrm{n}$ & $\%$ & $\mathrm{n}$ & $\%$ & & & \\
\hline \multirow{2}{*}{ Hotel size } & medium or large & 5 & 38.46 & 4 & 30.77 & 4 & 30.77 & \multirow{2}{*}{0.09} & \multirow{2}{*}{0.96} & \multirow{2}{*}{0.06} \\
\hline & small & 4 & 36.36 & 3 & 27.27 & 4 & 36.36 & & & \\
\hline \multirow{2}{*}{ Hotel location } & city center & 4 & 33.33 & 5 & 41.67 & 3 & 25.00 & \multirow{2}{*}{1.90} & \multirow{2}{*}{0.39} & \multirow{2}{*}{0.28} \\
\hline & outskirts & 5 & 41.67 & 2 & 16.67 & 5 & 41.67 & & & \\
\hline \multirow{2}{*}{ Hotel rating } & high & 4 & 50.00 & 3 & 37.50 & 1 & 12.50 & \multirow{2}{*}{2.35} & \multirow{2}{*}{0.31} & \multirow{2}{*}{0.31} \\
\hline & medium or low & 5 & 37.50 & 4 & 25.00 & 7 & 43.75 & & & \\
\hline \multirow{2}{*}{ Hotel type } & business & 7 & 50.00 & 6 & 42.86 & 1 & 7.14 & \multirow{2}{*}{10.47} & \multirow{2}{*}{$0.01 *$} & \multirow{2}{*}{0.66} \\
\hline & tourist & 2 & 20.00 & 1 & 10.00 & 7 & 70.00 & & & \\
\hline \multirow{2}{*}{$\begin{array}{l}\text { Degree } \\
\text { of integration }\end{array}$} & integrated & 5 & 45.45 & 5 & 45.45 & 1 & 9.09 & \multirow{2}{*}{5.77} & \multirow{2}{*}{0.06} & \multirow{2}{*}{0.49} \\
\hline & independent & 4 & 30.77 & 2 & 15.38 & 7 & 53.85 & & & \\
\hline
\end{tabular}

Note: $\chi^{2}$ - chi-squared distribution, $\mathrm{p}$ - probability value, $\mathrm{V}_{\mathrm{c}}-$ Cramer's $\mathrm{V}$, ${ }^{*}-\mathrm{p}<0.05$.

Source: author's own on the basis of the results of the survey. 
Table 5. The direction of the impact of the natural environment on hotels and selected functional characteristics of hotels

\begin{tabular}{|c|c|c|c|c|c|c|c|c|c|c|}
\hline \multirow{3}{*}{$\begin{array}{l}\text { Functional } \\
\text { characteristic }\end{array}$} & \multirow{3}{*}{ Variable } & \multicolumn{6}{|c|}{$\begin{array}{l}\text { Direction of impact of the natural environment on } \\
\text { a hotel }\end{array}$} & \multirow{3}{*}{$\chi^{2}$} & \multirow{3}{*}{$\mathrm{p}$} & \multirow{3}{*}{$\mathrm{V}_{\mathrm{c}}$} \\
\hline & & \multicolumn{2}{|c|}{ positive } & \multicolumn{2}{|c|}{ neutral } & \multicolumn{2}{|c|}{ negative } & & & \\
\hline & & $\mathrm{n}$ & $\%$ & $\mathrm{n}$ & $\%$ & $\mathrm{n}$ & $\%$ & & & \\
\hline \multirow{2}{*}{ Hotel size } & medium or large & 8 & 61.54 & 4 & 30.77 & 1 & 7.69 & \multirow{2}{*}{3.24} & \multirow{2}{*}{0.20} & \multirow{2}{*}{0.37} \\
\hline & small & 3 & 27.27 & 5 & 45.45 & 3 & 27.27 & & & \\
\hline \multirow{2}{*}{ Hotel location } & city center & 6 & 50.00 & 3 & 25.00 & 3 & 25.00 & \multirow{2}{*}{2.09} & \multirow{2}{*}{0.35} & \multirow{2}{*}{0.30} \\
\hline & outskirts & 5 & 41.67 & 6 & 50.00 & 1 & 8.33 & & & \\
\hline \multirow{2}{*}{ Hotel rating } & high & 4 & 50.00 & 3 & 37.50 & 1 & 12.50 & \multirow{2}{*}{0.17} & \multirow{2}{*}{0.92} & \multirow{2}{*}{0.08} \\
\hline & medium or low & 7 & 43.75 & 6 & 37.50 & 3 & 18.75 & & & \\
\hline \multirow{2}{*}{ Hotel type } & business & 8 & 57.14 & 4 & 28.57 & 2 & 14.29 & \multirow{2}{*}{1.77} & \multirow{2}{*}{0.41} & \multirow{2}{*}{0.27} \\
\hline & tourist & 3 & 30.00 & 5 & 50.00 & 2 & 20.00 & & & \\
\hline \multirow{2}{*}{$\begin{array}{l}\text { Degree } \\
\text { of integration }\end{array}$} & integrated & 5 & 45.45 & 4 & 36.36 & 2 & 18.18 & \multirow{2}{*}{0.04} & \multirow{2}{*}{0.98} & \multirow{2}{*}{0.04} \\
\hline & independent & 6 & 46.15 & 5 & 38.46 & 2 & 15.38 & & & \\
\hline
\end{tabular}

Note: $\chi^{2}-$ chi-squared distribution, $\mathrm{p}$ - probability value, $\mathrm{V}_{\mathrm{c}}-\mathrm{Cramer}$ 's $\mathrm{V}$, ${ }^{*}-\mathrm{p}<0.05$.

Source: author's own on the basis of the results of the survey.

There was a stochastic dependence between the strength of the hotel's environmental impact and the hotel's specific location and quality standard (hotel rating). The medium and high rating prevailed in downtown hotels, while the facilities on the outskirts of Wrocław were ranked rather low. The values of chi-squared distribution $\left(\chi^{2}=10.67, p=0.00\right)$ and Cramer's V $(V c=0.67)$ warrant the claim of a high correlation between the strength of the hotel's environmental impact and its specific location. On the other hand, when considering the quality standard (hotel star rating) of the studied hotels, it was noticed that the managers or owners of hotels of a high standard assessed the strength of a hotel's impact on the natural environment as high, and of a small and medium standard as mostly low. Also in this case there was a high correlation between the strength of this impact and the hotel rating $\left(\chi^{2}=10.13\right.$; $p=0.00 ; V c=0.65)$. No analogous correlation was noted in the assessment of the strength of the environmental impact and the size, type, and degree of integration of the surveyed hotels. Also, no statistically significant stochastic dependences (Tables 6,7) were found between the direction of the influence of hotels on the natural environment and all functional characteristics of the Wrocław hotels. 
Table 6 . The strength of the impact of hotels on the natural environment and selected functional characteristics of hotels

\begin{tabular}{|c|c|c|c|c|c|c|c|c|c|c|}
\hline \multirow{3}{*}{$\begin{array}{l}\text { Functional } \\
\text { characteristic }\end{array}$} & \multirow{3}{*}{ Variable } & \multicolumn{6}{|c|}{$\begin{array}{c}\text { Strength of impact of the hotel on the natural } \\
\text { environment }\end{array}$} & \multirow{3}{*}{$\chi^{2}$} & \multirow{3}{*}{$\mathrm{p}$} & \multirow{3}{*}{$\mathrm{V}_{\mathrm{c}}$} \\
\hline & & \multicolumn{2}{|c|}{ large } & \multicolumn{2}{|c|}{ medium } & \multicolumn{2}{|c|}{ small } & & & \\
\hline & & $\mathrm{n}$ & $\%$ & $\mathrm{n}$ & $\%$ & $\mathrm{n}$ & $\%$ & & & \\
\hline \multirow{2}{*}{ Hotel size } & medium or large & 5 & 38.46 & 4 & 30.77 & 4 & 30.77 & \multirow{2}{*}{4.53} & \multirow{2}{*}{0.10} & \multirow{2}{*}{0.43} \\
\hline & small & 1 & 9.09 & 2 & 18.18 & 8 & 72.73 & & & \\
\hline \multirow{2}{*}{ Hotel location } & city center & 5 & 41.67 & 5 & 41.67 & 2 & 16.67 & \multirow{2}{*}{10.67} & \multirow{2}{*}{$0.00 *$} & \multirow{2}{*}{0.67} \\
\hline & outskirts & 1 & 8.33 & 1 & 8.33 & 10 & 83.33 & & & \\
\hline \multirow{2}{*}{ Hotel rating } & high & 5 & 62.50 & 2 & 25.00 & 1 & 12.50 & \multirow{2}{*}{10.13} & \multirow{2}{*}{$0.00 *$} & \multirow{2}{*}{0.65} \\
\hline & medium or low & 1 & 6.25 & 4 & 25.00 & 11 & 68.75 & & & \\
\hline \multirow{2}{*}{ Hotel type } & business & 5 & 35.71 & 3 & 21.43 & 6 & 42.86 & \multirow{2}{*}{2.06} & \multirow{2}{*}{0.36} & \multirow{2}{*}{0.29} \\
\hline & tourist & 1 & 10.00 & 3 & 30.00 & 6 & 60.00 & & & \\
\hline \multirow{2}{*}{$\begin{array}{l}\text { Degree } \\
\text { of integration }\end{array}$} & integrated & 5 & 45.45 & 3 & 27.27 & 3 & 27.27 & \multirow{2}{*}{5.54} & \multirow{2}{*}{0.06} & \multirow{2}{*}{0.48} \\
\hline & independent & 1 & 7.69 & 3 & 23.08 & 9 & 69.23 & & & \\
\hline
\end{tabular}

Note: $\chi^{2}$ - chi-squared distribution, $\mathrm{p}$ - probability value, $\mathrm{V}_{\mathrm{c}}-\mathrm{Cramer}$ 's $\mathrm{V}$, ${ }^{*}-\mathrm{p}<0.05$.

Source: author's own on the basis of survey results.

Table 7. The direction of the impact of hotels on the natural environment and selected functional characteristics of hotels

\begin{tabular}{|c|c|c|c|c|c|c|c|c|c|c|}
\hline \multirow{3}{*}{$\begin{array}{c}\text { Functional } \\
\text { characteristic }\end{array}$} & \multirow{3}{*}{ Variable } & \multicolumn{6}{|c|}{$\begin{array}{c}\text { Direction of impact of the hotel on the natural } \\
\text { environment }\end{array}$} & \multirow{3}{*}{$\chi^{2}$} & \multirow{3}{*}{$\mathrm{p}$} & \multirow{3}{*}{$\mathrm{V}_{\mathrm{c}}$} \\
\hline & & \multicolumn{2}{|c|}{ positive } & \multicolumn{2}{|c|}{ neutral } & \multicolumn{2}{|c|}{ negative } & & & \\
\hline & & $\mathrm{n}$ & $\%$ & $\mathrm{n}$ & $\%$ & $\mathrm{n}$ & $\%$ & & & \\
\hline \multirow{2}{*}{ Hotel size } & medium or large & 4 & 30.77 & 6 & 46.15 & 3 & 23.08 & \multirow{2}{*}{0.98} & \multirow{2}{*}{0.61} & \multirow{2}{*}{0.20} \\
\hline & small & 4 & 36.36 & 3 & 27.27 & 4 & 36.36 & & & \\
\hline \multirow{2}{*}{ Hotel location } & city center & 6 & 50.00 & 4 & 33.33 & 2 & 16.67 & \multirow{2}{*}{3.40} & \multirow{2}{*}{0.18} & \multirow{2}{*}{0.38} \\
\hline & outskirts & 2 & 16.67 & 5 & 41.67 & 5 & 41.67 & & & \\
\hline \multirow{2}{*}{ Hotel rating } & high & 4 & 30.77 & 6 & 46.15 & 3 & 23.08 & \multirow{2}{*}{2.14} & \multirow{2}{*}{0.34} & \multirow{2}{*}{0.30} \\
\hline & medium or low & 4 & 36.36 & 3 & 27.27 & 4 & 36.36 & & & \\
\hline \multirow{2}{*}{ Hotel type } & business & 4 & 28.57 & 5 & 35.71 & 5 & 35.71 & \multirow{2}{*}{0.75} & \multirow{2}{*}{0.69} & \multirow{2}{*}{0.18} \\
\hline & tourist & 4 & 40.00 & 4 & 40.00 & 2 & 20.00 & & & \\
\hline \multirow{2}{*}{$\begin{array}{l}\text { Degree } \\
\text { of integration }\end{array}$} & integrated & 4 & 36.36 & 4 & 36.36 & 3 & 27.27 & \multirow{2}{*}{0.09} & \multirow{2}{*}{0.96} & \multirow{2}{*}{0.06} \\
\hline & independent & 4 & 30.77 & 5 & 38.46 & 4 & 30.77 & & & \\
\hline
\end{tabular}

Note: $\chi^{2}$ - chi-squared distribution, $\mathrm{p}$ - probability value, $\mathrm{V}_{\mathrm{c}}-\mathrm{Cramer}$ 's $\mathrm{V}$, ${ }^{*}-\mathrm{p}<0.05$.

Source: author's own on the basis of the results of the survey. 


\section{Conclusions}

Changes in the natural environment and the need for hotel companies and their microsurroundings (e.g. competitors or suppliers) and macro-surroundings (e.g. legal, economic, social, and technological) to adapt to them, both from a national and international perspective, make the issues addressed in the study important and topical.

Summarizing the results of the conducted research and responding to the objectives and specific research problems, the following conclusions can be formulated:

1. In the opinion of the highest percentage of respondents, the interactions between the natural environment and the Wroclaw hotels are low and neutral.

2. The use of natural resources, availability of resources necessary for providing services, and attractive geographical location were considered to be the most significant positive effects of the environmental impact on the studied Wrocław hotels. The main negative effects were air pollution and shortage of natural assets.

3. The positive effects of hotels functioning in a specific natural environment included environmental awareness improvement, pollution prevention, limited volume of used resources, and use of recycled materials. The main negative environmental effects of the operation of the Wrocław hotels were water consumption, waste generation, pollution emissions, sewage production, and food waste.

4. The type of hotel was associated with the strength of the environmental impact on the hotel. Representatives of business hotels assessed it mostly as medium or high and of tourist hotels as low.

5. In the surveyed sample of the Wrocław hotels there were significant correlations between the strength of the hotel's impact on the natural environment and the specific location and the hotel quality standard (star rating). Average and high ratings dominated in highly rated downtown hotels, while low ratings in low- and medium-standard hotels located on the outskirts of the city.

The article has its strengths and weaknesses. The main advantage of the article is its main research problem, since potential correlations between the assessment of the strength and directions of the interactions between the hotel and the natural environment, and the organizational and functional characteristics of hotels, have not been analyzed so far. Earlier studies on the functioning of hotels in the natural environment did not include urban tourist hotels either. These two issues determine the scientific contribution of the study. However, the main shortcoming of the study is that its spatial scope is too narrow. The examined sample was 
not representative, so the formulated conclusions concern only the examined hotels. Further research should be conducted in hotels located all over Poland and in countries with a similar level of hotel market development. This will make it possible not only to draw conclusions regarding the general population, but also to capture the possible differences between hotels located in different regions or countries, spatial units (villages, small towns, big cities), and reception areas (cities, tourist destinations).

\section{References}

Adamczyk, J., Nitkiewicz, T. (2007). Programowanie zrównoważonego rozwoju przedsiębiorstw. Warszawa: Polskie Wydawnictwo Ekonomiczne.

Asadi, S., Pourhashemi, S., Nilashi, M., Abdullah, R., Samad, S., Yadegaridehkordi, E., Aljojo, N., Razali, N. (2020). Investigating influence of green innovation on sustainability performance: A case on Malaysian hotel industry. Journal of Cleaner Production, 258. DOI: 10.1016/j.jclepro.2020.120860.

Bednarska, M., Gołembski, G., Markiewicz, E., Olszewski, M. (2007). Przedsiębiorstwo turystyczne. Ujęcie statyczne i dynamiczne. Warszawa: PWE.

Borkowska-Niszczota, M. (2015). Społeczna odpowiedzialność biznesu turystycznego na rzecz zrównoważonego rozwoju na przykładzie obiektów hotelarskich. Economics and Management, 1, 368-392. DOI: 10.12846/j.em.2015.01.23.

Borys, T. (2011). Sustainable development - How to recognize integrated order. Problemy Ekorozwoju, 6 (2), 75-81.

Bugdol, M., Puciato, D., Borys, T. (2019). Zachowania prośrodowiskowe w hotelach w kontekście zrównoważonego rozwoju turystyki - bariery i rekomendacje dla dalszych badań. Problemy Ekorozwoju, 14 (2), 157-170.

Chan, W. (2009). Environmental measures for hotels' environmental management systems ISO 14001. International Journal of Contemporary Hospitality Management, 21 (4-5), 542560. DOI: 10.1108/09596110910967791.

Chan, E., Wong, S. (2006). Motivations for ISO 14001 in the hotel industry. Tourism Management, 27 (3), 481-492. DOI: 10.1016/j.tourman.2004.10.007.

Chen, L. (2019). Green certification, e-commerce, and low-carbon economy for international tourist hotels. Environmental Science and Pollution Research, 26 (18), 17965-17973. DOI: $10.1007 / \mathrm{s} 11356-018-2161-5$.

Fiedor, B. (2002). Podstawy ekonomii środowiska i zasobów naturalnych. Warszawa: C.H. Beck. 
Fraj, E., Matute, J., Melero, I. (2015). Environmental strategies and organizational competitiveness in the hotel industry: The role of learning and innovation as determinants of environmental success. Tourism Management, 46, 30-42. DOI: 10.1016/j.tourman.2014.05.009.

Fura, B. (2011) System zarządzania środowiskowego ISO 14001 a efektywność przedsiębiorstw. Rzeszów: Uniwersytet Rzeszowski.

Han, H., Yu, J., Hyun, S. (2020). Effects of nature-based solutions (NBS) on eco-friendly hotel guests' mental health perceptions, satisfaction, switching barriers, and revisit intentions. Journal of Hospitality Marketing \& Management, 29 (5), 592-611. DOI: 10.1080/19368623.2019.1660751.

Jedynak, J. (2017). Znormalizowane systemy zarządzania a ryzyko działalności organizacji. Kraków: Wydawnictwo Uniwersytetu Jagiellońskiego.

Juvan, E., Dolnicar, S. (2017). Drivers of pro-environmental tourist behaviours are not universal. Journal of Cleaner Production, 166, 879-890. DOI: 10.1016/j.jclepro.2017.08.087.

Kapera, I. (2018). Rozwój zrównoważony w hotelarstwie - między teorią a praktyką w Polsce. Turyzm, 28 (2), 25-32. DOI: 10.18778/0867-5856.28.2.03.

Kapera, I., Wszendybył-Skulska, E. (2017). Działania proekologiczne w ocenie gości hoteli. Turyzm, 27 (2), 59-64. DOI: 10.18778/0867-5856.27.2.05.

Kim, Y., Kim, W., Choi, H. Phetvaroon K. (2019). The effect of green human resource management on hotel employees' ecofriendly behavior and environmental performance. International Journal of Hospitality Management, 76, 83-93. DOI: 10.1016/j.ijhm.2018.04.007.

Kiryluk, H., Borkowska-Niszczota, M. (2006). Koncepcja turystyki zrównoważonej w teorii i praktyce. In: A. Nowakowska, M. Przydział (eds.), Turystyka w badaniach naukowych. Rzeszów: Wydawnictwo Wyższej Szkoły Informatyki i Zarządzania.

Kłos, A. (2013). Proekologiczne rozwiązania w obiektach hotelarskich. Zeszyty Naukowe. Turystyka i Rekreacja, 11 (1), 147-165.

Kożuch, M. (2012). Inwestycje ekologiczne a konkurencyjność przedsiębiorstw. Zeszyty Naukowe Uniwersytetu Szczecińskiego. Studia i Prace Wydziału Nauk Ekonomicznych i Zarządzania, 25, 331-342.

Li, L., Lu, L., Xu, Y., Sun, X., The spatiotemporal evolution and influencing factors of hotel industry in the metropolitan area: An empirical study based on China. Plos One, 15 (5). DOI: 10.1371/journal.pone.0231438.

Najda-Janoszka, M. (2010). Wspólnotowe oznakowanie ekologiczne w turystyce. Oeconomia, $9(4), 333-343$.

Niezgoda, A. (2004). Problemy wprowadzania turystyki zrównoważonej w Polsce. Studia Turystyczne, 1, 76-90. 
Niezgoda, A., Markiewicz, E. (2015). Turystyka biznesowa a turystyka zrównoważona przykład hotelu w aglomeracji. Zeszyty Naukowe Wyższej Szkoły Bankowej w Poznaniu, $63(6), 225-240$.

Ouyang, Z., Wei, W., Chi, C. (2019). Environment management in the hotel industry: does institutional environment matter? International Journal of Hospitality Management, 77, 353-364. DOI: 10.1016/j.ijhm.2018.07.015.

Ozimek, I., Szlachciuk, J., Kulykovets, O., Przeździecka-Czyżewska, N. (2017). Factors influencing the choice and quality assessment of hotel facilities in Poland. Folia Oeconomica Stetinensia, 17 (1), 170-181. DOI: 10.1515/foli-2017-0014.

Panasiuk, A. (2017). Financing tourism development of environmentally valuable areas in regional operational programmes in the European Union financial perspectives for 20072013 and 2014-2020. Ekonomia i Środowisko, 61 (2), 255-264.

Puciato, D., Żmigrodzki, M. (2009). Zmiany w makrootoczeniu a funkcjonowanie współczesnych przedsiębiorstw hotelarskich. Zeszyty Naukowe Małopolskiej Wyższej Szkoły Ekonomicznej w Tarnowie, 14 (3), 85-94.

Puciato, D., Goranczewski, B. (2011). Systemy zarządzania środowiskowego jako narzędzie budowania świadomości ekologicznej u interesariuszy przedsiębiorstw turystycznych. In: E. Dziedzic (ed.), Turystyka wobec nowych zjawisk $w$ gospodarce światowej. Warszawa: Szkoła Główna Handlowa.

Puciato, D. (2016). Attractiveness of municipalities in South-Western Poland as determinants for hotel chain investments. Tourism Management, 57, 245-255. DOI: 10.1016/j.tourman.2016.06.019.

Puciato, D., Dziedzic, E. (2017). Attractiveness of South-West Poland municipalities for independent hotel investors. Tourism Economics, 23 (3), 702-711. DOI: 10.5367/te.2016.0539.

Raczkowski, K., Sułkowski, Ł., Fijałkowska, J. (2016). Comparative critical review of corporate social responsibility business management models. International Journal of Contemporary Management, 15 (2), 123-150.

Saito O. (2017). Future science-policy agendas and partnerships for building a sustainable society in harmony with nature. Sustainability Science, 12 (6), 895-899. DOI: 10.1007/ s11625-017-0475-8.

Sidorkiewicz, M., Tokarz, A. (2011). Otoczenie jako źródło ryzyka w działalności przedsiębiorstw hotelarskich. Ekonomiczne Problemy Ustug, 73, 453-461.

Strzembicki, L. (2001). Zrównoważony rozwój turystyki wiejskiej - założenia i formy realizacji. Problemy Turystyki, 3-4, 31-41.

Sztorc, M. (2017). Problematyka zrównoważonego rozwoju oparta na wartościach w strategiach przedsiębiorstw hotelarskich. Studia i Materiaty. Miscellanea Oeconomicae, 21 (2), 303-314. 
Yu, J., Ariza-Montes, A., Hernandez-Perlines, F., Vega-Munoz, A., Han, H. (2020). Hotels' eco-friendly physical environment as nature-based solutions for decreasing burnout and increasing job satisfaction and performance. International Journal of Environmental Research and Public Health, 17 (17). DOI: 10.3390/ijerph17176357.

Yucedag, C., Kaya, L., Cetin, M. (2018). Identifying and assessing environmental awareness of hotel and restaurant employees' attitudes in the Amasra District of Bartin. Environmental Monitoring and Assessment, 190, 60. DOI: 10.1007/s10661-017-6456-7.

Yusoff, M., Nejati, N., Kee, D. (2018). Linking green human resource management practices to environmental performance in hotel industry. Global Business Review, 2, 663-680. DOI: $10.1177 / 0972150918779294$. 